\title{
Analytical Method Development and Validation of Dimethoate Pesticide using HPLC Method
}

\author{
C. Pavan Kumar* and B. M. Gurupadayya \\ Department of Pharmaceutical Analysis, JSS College of Pharmacy, JSS University, Mysore - 570 015, Karnataka, India
}

\section{Overview}

Dimethoate (Figure 1) is a widely used organophosphate insecticide used to kill insects on contact. It was patented and introduced in the 1950s by American Cyanamid. Like other organophosphates, dimethoate is an anti-cholinesterase which disables cholinesterase, an enzyme essential for central nervous system function [1]. The literature survey, it was found that dimethoate estimated by analytical methods such reversed-phase high performance liquid chromatographic HPLC method [2] and some spectrophotometric methods like mass spectrophotometry. The HPLC method has its relative merits but the majority of them are carried out at elevated temperatures, time consuming, use relatively expensive reagents, involve extraction, use of buffer system. In this report, we present one simple, sensitive, cost-effective and accurate method for the determination of dimethoate [3].

\section{Materials and Methods}

\section{Instrumentation}

A HPLC equipped with UV detector was used for the present research work. The separation was achieved using Phenomenex luna C18 column $250 \times 4.6$

\section{Chemicals and reagents}

Dimethoate sample was purchased from Sigma-Aldrich Company. All the chemicals are of analytical reagent grade of Merck Pharmaceuticals. HPLC grade water was used to prepare all solutions.

\section{Method development}

Selection and preparation of mobile phase: Various mobile phases were tried in different ratios for selection of mobile phase. The drug Dimethoate was injected with different mobile phases at different ratios with different flow rates till a sharp peak, without any interference peaks containing spectrum was obtained. The mobile phase selected was acetonitrile and water in the ratio $60: 40(\mathrm{v} / \mathrm{v})$.

\section{Preparation of solutions}

Stock and standard solution: Stock solutions of Dimethoate working standard was prepared by dissolving $10 \mathrm{mg}$ of drug in $10 \mathrm{~mL}$ of methanol, so that final concentration is $1 \mathrm{mg} / \mathrm{mL}$. From the stock solution $5,10,15,20,25 \mu \mathrm{g} \mathrm{mL}^{-1}$ dilutions were prepared by using methanol as diluents.

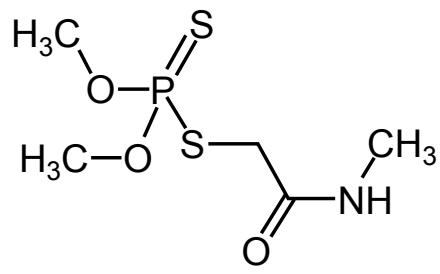

Figure 1: Dimethoate.

\section{Sample preparation}

$3 \mathrm{ml}$ of pesticide sample was taken and to this $3 \mathrm{ml}$ of organic solvent (benzene) was added, shake the solution well and then centrifuge it for $10 \mathrm{~min}$ at $2000 \mathrm{rpm}$. Evaporate the organic layer under reduced pressure passing nitrogen gas for 1 hour. Collect the residue and dissolve it in 2 $\mathrm{ml}$ methanol and sample was filtered by using $0.45 \mu$ syringe filters, and injected into column (Table 1).

\section{Method validation}

Linearity: The linearity of an analytical method is its ability to elicit test results that are directly or by a well-defined mathematical transformation proportional to the concentration of analyte in samples within a given range. The calibration curves were constructed with five concentrations ranging from 5 to $25 \mu \mathrm{g} / \mathrm{mL}$ (Table 2). The linearity was evaluated by linear regression analysis, which was calculated by least square method (Figure 2).

\begin{tabular}{|l|l|}
\hline & HPLC 2010 \\
\hline Column & Phenomenex luna C18 column 250×4.6 \\
\hline Wavelength & $205 \mathrm{~nm}$ \\
\hline Temperature & $30^{\circ} \mathrm{C}$ \\
\hline Flow rate & $1.0 \mathrm{ml} / \mathrm{min}$ \\
\hline Detector & $\mathrm{UV}$ \\
\hline Injection volume & $10 \mu \mathrm{l}$ \\
\hline Mobile phase & Acetonitrile, Water in the ratio of $60: 40(\mathrm{v} / \mathrm{v})$ \\
\hline Retention time & 4.76 min \\
\hline
\end{tabular}

Table: Solution preparation.

\begin{tabular}{|l|l|}
\hline Parameters determined & Obtained values \\
\hline Linearity & $5-25\left(\mu \mathrm{mL}^{-1}\right)$ \\
\hline Regression equation $(\mathrm{Y}=\mathrm{mx}+\mathrm{c})$ & $\mathrm{Y}=9984 \mathrm{x}+1509.6$ \\
\hline Slope & 9984 \\
\hline Intercept & 1509.6 \\
\hline Regression coefficient & 0.9967 \\
\hline LOD & $0.11\left(\mu \mathrm{gL}^{-1}\right)$ \\
\hline LOQ & $0.33\left(\mu \mathrm{gL}^{-1}\right)$ \\
\hline
\end{tabular}

Table 2: Method parameters.

*Corresponding author: C. Pavan Kumar, Department of Pharmaceutical Analysis, JSS College of Pharmacy, JSS University, Mysore-570 015, Karnataka, India, E-mail: pavankumar9737@gmail.com

Received December 18, 2012; Accepted February 12, 2013; Published February 15,2013

Citation: Pavan Kumar C, Gurupadayya BM (2013) Analytical Method Development and Validation of Dimethoate Pesticide using HPLC Method. Biochem Anal Biochem 2: 127. doi:10.4172/2161-1009.1000127

Copyright: (c) 2013 Pavan Kumar C, et al. This is an open-access article distributed under the terms of the Creative Commons Attribution License, which permits unrestricted use, distribution, and reproduction in any medium, provided the original author and source are credited. 
Citation: Pavan Kumar C, Gurupadayya BM (2013) Analytical Method Development and Validation of Dimethoate Pesticide using HPLC Method. Biochem Anal Biochem 2: 127. doi:10.4172/2161-1009.1000127

Page 2 of 3

Accuracy: The accuracy of the method is the closeness of the measured value to the true value for the sample. To determine the accuracy of the proposed method, different levels of drug concentrations - lower concentration (LC, 80\%), intermediate concentration (IC, $100 \%$ ) and higher concentration (HC, 120\%) were prepared from independent stock solutions and analysed. Accuracy was assessed as the percentage relative error and mean \% recovery (Table 3).

Precision: Repeatability was determined by using different levels of drug concentrations (same concentration levels taken in accuracy study), prepared from independent stock solutions and analyzed. Interday, intra-day and inter instrument variation were studied to determine intermediate precision of the proposed analytical methods (Table 2).
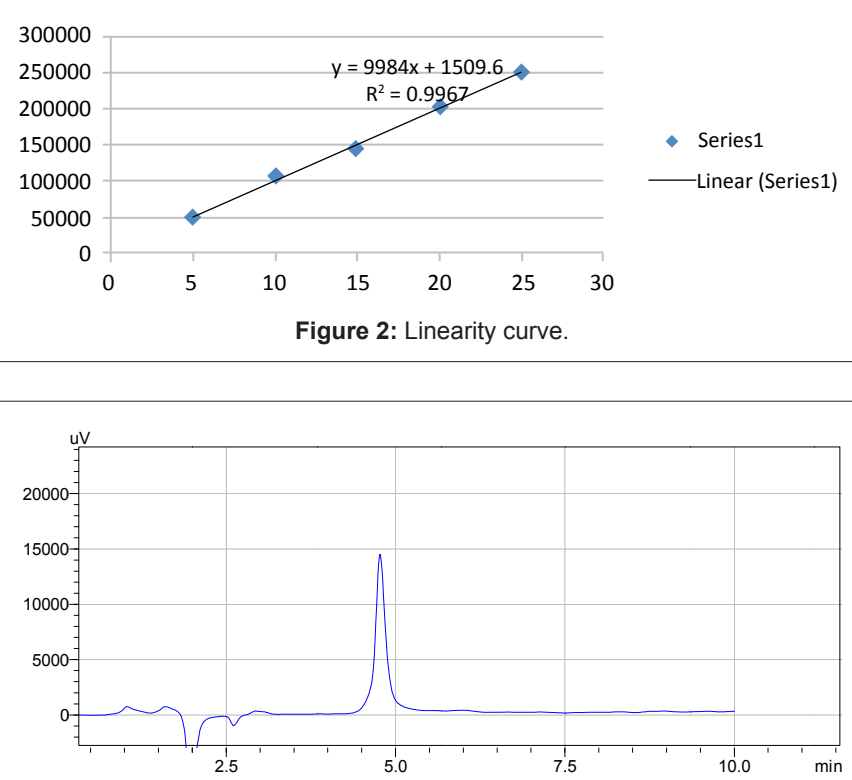

Figure 3: Standard chromatogram.
Different levels of drug concentrations (6 times) were prepared, three different times in a day and studied for intraday variation (Table 3 ).

Limit of Detection (LOD) and Limit of Quantitation (LOQ): The LOD and LOQ for dimethoate by the proposed method were determined using calibration standards. Limit of detection can be calculated as per ICH guidelines using following equation, $\mathrm{LOD}=3.3 \times \mathrm{N} / \mathrm{S}$. Where, $\mathrm{N}$ is the standard deviation of the peak areas of the drug and $\mathrm{S}$ is the slope of the corresponding calibration curve. Limit of quantification can be calculated as per ICH guidelines using following equation, $\mathrm{LOQ}=10 \times \mathrm{N} / \mathrm{S}$ where, $\mathrm{N}$ is the standard deviation of the peak areas of the drug and $\mathrm{S}$ is the slope of the corresponding calibration curve.

\section{Result and Discussion}

A simple accurate and precised HPLC method for the determination of dimethoate pesticide was developed. The method was validated according to ICH guidelines. From the chromatogram retention time was found to be $4.75 \mathrm{~min}$ (Figure 3), with a correlation coefficient $\left(\mathrm{r}^{2}\right)$ of 0.9967. The limit of detection (LOD) was calculated and found to be $0.11 \mu \mathrm{g}$ and limit of quantification (LOQ) was found to be $0.33 \mu \mathrm{g}$. Intraday precision values \% RSD values were found to be 0.171 and interday precision values were found to be 0.205 respectively.

\section{Conclusion}

This is the simple, accurate method for the determination of dimethoate and validated as per ICH guidelines. The proposed method did not require not more than 10 min for analysis. The methods can be considered for the determination of dimethoate in quality control laboratories, the work can be continued to bioanalytical samples also.

\section{References}

1. Aleksandra NK, Meri M, Jean JA, Zoran Z (2008) Determination of dimethoate, 2,4-dichlorophenoxy acetic acid, mecoprop and linuron pesticides in environmental waters in republic of macedonia by high performance liquid chromatography. Macedonian Journal of Chemistry and Chemical Engineering $27: 25-33$.

\begin{tabular}{|c|c|c|c|c|c|c|c|}
\hline S. No & $\begin{array}{l}\text { Amount of drug } \\
\text { taken }\left(\mu \mathrm{g} \mathrm{mL} \mathrm{m}^{-1}\right)\end{array}$ & $\begin{array}{l}\text { Amount of drug } \\
\text { added in } \\
\left(\mu g \mathrm{~mL}^{-1}\right) \text { Injection }\end{array}$ & $\begin{array}{l}\text { Total Amount of } \\
\text { drug in }\left(\mu \mathrm{g} \mathrm{mL}^{-1}\right)\end{array}$ & $\begin{array}{l}\text { Total Amount of } \\
\text { drug found }\end{array}$ & $\%$ Recovery & $\begin{array}{l}\text { Average recovery } \\
\text { in } \%\end{array}$ & \% RSD \\
\hline \multirow[b]{3}{*}{1} & \multirow[b]{3}{*}{8} & \multirow{3}{*}{ 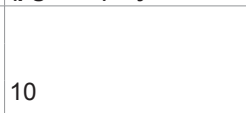 } & \multirow[b]{3}{*}{18} & 17.86 & 99.24 & \multirow{3}{*}{98.97} & \multirow{3}{*}{0.47} \\
\hline & & & & 17.85 & 99.17 & & \\
\hline & & & & 17.73 & 98.51 & & \\
\hline \multirow[b]{3}{*}{2} & \multirow[b]{3}{*}{10} & \multirow[b]{3}{*}{10} & \multirow[b]{3}{*}{20} & 19.83 & 99.13 & \multirow{3}{*}{99.35} & \multirow{3}{*}{0.70} \\
\hline & & & & 20.023 & 100.14 & & \\
\hline & & & & 19.76 & 98.78 & & \\
\hline \multirow[b]{3}{*}{3} & \multirow[b]{3}{*}{12} & \multirow[b]{3}{*}{10} & \multirow[b]{3}{*}{22} & 22.09 & 100.44 & \multirow{3}{*}{101.23} & \multirow{3}{*}{1.16} \\
\hline & & & & 22.68 & 102.58 & & \\
\hline & & & & 22.15 & 100.68 & & \\
\hline
\end{tabular}

Table 3: Accuracy studies (Recovery studies).

\begin{tabular}{|c|c|c|c|c|c|c|c|c|}
\hline \multirow[b]{2}{*}{ S.NO } & \multicolumn{4}{|l|}{ INTRA DAY } & \multicolumn{4}{|l|}{ INTER DAY } \\
\hline & $\begin{array}{l}\text { Amount of Drug } \\
\text { taken }\left(\mu \mathrm{g} \mathrm{mL}^{-1}\right)\end{array}$ & $\begin{array}{l}\text { Amount of drug } \\
\text { found }\left(\mu \mathrm{gL}^{-1}\right)\end{array}$ & Mean & \%RSD & $\begin{array}{l}\text { Amount of Drug } \\
\text { taken }\left(\mu \mathrm{g} \mathrm{mL}^{-1}\right.\end{array}$ & $\begin{array}{l}\text { Amount of drug } \\
\text { found }\left(\mu \mathrm{gL}^{-1}\right)\end{array}$ & Mean & \%RSD \\
\hline 1 & \multirow{6}{*}{20} & 20.18 & \multirow{6}{*}{20.17} & \multirow{6}{*}{0.17} & \multirow{6}{*}{20} & 18.14 & \multirow{6}{*}{18.17} & \multirow{6}{*}{0.21} \\
\hline 2 & & 20.18 & & & & 18.23 & & \\
\hline 3 & & 20.15 & & & & 18.12 & & \\
\hline 4 & & 20.18 & & & & 18.15 & & \\
\hline 5 & & 20.13 & & & & 18.17 & & \\
\hline 6 & & 20.23 & & & & 18.17 & & \\
\hline
\end{tabular}

Table 4: Precision (Intra day-Inter day). 
Citation: Pavan Kumar C, Gurupadayya BM (2013) Analytical Method Development and Validation of Dimethoate Pesticide using HPLC Method. Biochem Anal Biochem 2: 127. doi:10.4172/2161-1009.1000127

Page 3 of 3

2. Bagyalakshmi J, Kavitha G, Ravi TK (2011) Residue determination of dimethoate in Leafy vegetables (spinach) using RP-HPLC. International Journal of Pharma Sciences and Research 2: 62-64.
3. Grahovac ZM, Mitic SS, Pecev ET, Pavlovi AN (2010) Development of New Kinetic-spectrophotometric Method for Determination Insecticide Dimethoate in Milk and Water. Journal of the Chinese Chemical Society 57: 1027-1034

Citation: Pavan kumar C, Gurupadayya BM (2013) Analytical Method

Development and Validation of Dimethoate Pesticide using HPLC Method. Biochem Anal Biochem 2: 127. doi:10.4172/2161-1009.1000127 